\title{
POLH wt Allele
}

National Cancer Institute

\section{Source}

National Cancer Institute. POLH wt Allele. NCI Thesaurus. Code C91286.

Human POLH wild-type allele is located in the vicinity of $6 \mathrm{p} 21.1$ and is approximately 44 $\mathrm{kb}$ in length. This allele, which encodes DNA polymerase eta protein, is involved in the mediation of the repair of UV-damaged DNA. Mutation of the gene is associated with xeroderma pigmentosum variant type. 